\title{
Effects of Ultraviolet Irradiation, Hot Water Dip and Ethanol Vapours Treatment on Keeping Quality of Moth Bean (Phaseolus aconitifolius Jacq.) Sprouts
}

\author{
Simran Arora*, Saleem Siddiqui and Rakesh Gehlot \\ Centre of Food Science and Technology, CCSHAU, Hissar-125 004, Haryana, India \\ *Corresponding author
}

\section{A B S T R A C T}

Keywords

Ethanol vapours,

Hot water dip,

Moth bean

sprouts, Sensory

properties,

Ultraviolet

irradiation.

Article Info

Accepted:

19 June 2017

Available Online:

10 August 2017
The aim of this study was to investigate the effects of UV- irradiation, hot water dip (HWD) and ethanol vapours on the quality and storage life of moth bean sprouts (Phaseolus aconitifolius Jacq.). Moth bean seeds were washed, soaked and allowed to sprout. The sprouts were subjected to various treatments viz., ethanol vapour (30 min), hot water $\operatorname{dip}\left(50^{\circ} \mathrm{C}\right.$ for $\left.2 \mathrm{~min}\right)$ and UV-Irradiation $\left(10 \mathrm{kJm}^{-2}\right.$ for $\left.1 \mathrm{~h}\right)$. The sprouts were then packed in disposable glasses, wrapped with perforated cling films and stored at room $\left(25 \pm 3^{0} \mathrm{C}\right)$ and low $\left(7 \pm 0.5^{\circ} \mathrm{C}\right)$ temperature. The sprouts were analyzed at $24 \mathrm{~h}$ interval until the spoilage. Sprout length, weight and total plate count were increased during storage at both the storage temperature. There was no significant effect of various treatments on sprout length and weight, except in ethanol treatment, where suppression was observed. The total plate count was not significantly affected by various treatments. Sensory quality (for appearance, taste, odour and overall acceptability) decreased with increasing storage period. Throughout the storage period, there was no significant effect of various treatments except hot water dip treatment on the overall acceptability score of sprouts over control. The sprout continued to show acceptable scores upto $24 \mathrm{~h}$ at room temperature and $96 \mathrm{~h}$ at low temperature storage conditions, except in hot water dip treatment, where the keeping quality of moth bean sprouts was maintained upto $48 \mathrm{~h}$ at room temperature and $120 \mathrm{~h}$ at low temperature.

\section{Introduction}

Moth bean (Phaseolus aconitifolius Jacq.), being one of the most drought resistant pulses, is widely grown under rainfed condition in semi-arid and arid zones of India. It contains $24.1 \%$ protein, $0.8 \%$ crude fibre, $1.3 \%$ fat and 3\% ash (Bhattacharya, 2010). The seeds of moth beans contains high amount of anti-nutritional factors like phytates, trypsin inhibitor (Salve and Mehrajfatema, 2011). Sprouting has been identified as an effective method for improving the nutritional quality of legumes (Khattak et al., 2008) coupled with reduction in anti-nutritional factors (Ghavidel and Prakash, 2007). Due to high moisture content and high metabolic activity, sprouts are highly perishable. The rapid quality loss at relatively modest temperature emphasizes the critical need to enhance shelf life and maintain the keeping quality of sprouts during storage. It is reported that pre-treatment of fresh cut mango with UV-C helped in maintaining its 
nutritional quality, preventing decay and extending storage life up to 15 days (George, 2015). Ethanol vapour treatment and hot water dip treatment enhanced the nutritional quality and shelf life (by inhibition of enzymatic browning) of mung bean sprouts (Goyal and Siddiqui, 2014). The shelf life of sprouts is very limited, restricted to two days. The use of various treatments generally regarded as safe (GRAS) pre-treatments, low temperature storage conditions, modified atmosphere packaging, etc. have been reported to enhance the shelf life of mung bean sprouts (Day, 1990; Goyal et al., 2014).

Keeping in view the nutritional importance of moth bean and its sprouts, the present investigation was undertaken to study the effect of various pre-treatments on nutritional quality of moth bean sprouts during storage.

\section{Materials and Methods}

\section{Plant material}

Moth beans variety HM-61 was procured from Forage Section, Department of genetics and Plant Breeding, CCS HAU, Hisar, Haryana, India. Moth bean seeds were cleaned, washed in hypochlorite solution and soaked 4 to 5 volumes of water $\left(22-25^{\circ} \mathrm{C}\right)$ for $10 \mathrm{~h}$ under ambient laboratory conditions. After soaking, seed were allowed to germinate in sprout maker (Novelle Plast, Delhi) for $24 \mathrm{~h}$ at $30 \pm 1^{\circ} \mathrm{C}$.

\section{Treatment and storage conditions}

Sprouted moth bean were divided into 4 lots of equal amount and subjected to various treatments viz., hot water dip (HWD) $\left(50{ }^{\circ} \mathrm{C}\right.$ for $2 \mathrm{~min}$ ), ethanol vapours (in a glass chamber saturated with ethanol vapours) for 30 min., and UV irradiation $\left(10 \mathrm{kJm}^{-2}\right.$ for $1 \mathrm{~h}$ in laminar flow chamber). Untreated sprouts were used as control. The sprouts from each treatment were filled in disposable plastic glasses ( 200 ml volume) and wrapped with $2 \%$ perforated cling films. Wet filter paper was placed along the inner sides of plastic glasses to maintain high humidity inside. There was $\sim 100 \mathrm{~g}$ sprouts per pack and the packs were stored in dark at room $\left(30 \pm 3^{\circ} \mathrm{C}\right)$ and low $\left(7 \pm 0.5^{\circ} \mathrm{C}\right)$ temperature conditions maintained in B.O.D. incubator. The sampling for various parameters was done regularly at $24 \mathrm{~h}$ interval until the spoilage.

\section{Parameter analyzed}

Physicochemical parameters for each treatment and control were assessed for sprout length, sprout weight, microbial and sensory quality.

\section{Sprout length and weight}

Length of the sprouts was measured by taking the mean of hypocotyls length of 10 sprouts and expressed in $\mathrm{cm}$. Weight was measured by taking the mean of ten sprouts without seed coat and was expressed in gram.

\section{Microbial analyses}

Ten gram sprouts were dipped in $90 \mathrm{ml}$ of distilled water for $1 \mathrm{~h}$ and then water samples were diluted by serial dilution technique. Then $0.1 \mathrm{ml}$ aliquot of the appropriate dilution was transferred to plate contain solidified potato dextrose agar and Nutrient agar. The plates were incubated in a BOD incubator at $30^{\circ} \mathrm{C}$ for $48 \mathrm{~h}$. The colonies were counted and results were expressed as log $\mathrm{cfu} / \mathrm{g}$.

\section{Sensory evaluation}

Sensory evaluation of experimental samples were conducted at different intervals of storage by semi trained taste panel of 10 trained judges and were evaluated for 
appearance, odour and taste. Overall acceptability (OA) of sample was calculated as mean score given to it by a judge for these parameters. The judges scored the quality characteristics of each sample on nine-point hedonic scale. The product with an overall score of 5 or above was considered acceptable.

\section{Statistical analysis}

Three replicates of each treated samples were used for analysis. The data obtained in the present investigation was subjected to analysis of variance (ANOVA) technique and analyzed according to two factorial completely randomized designs (CRD). The critical difference value at $5 \%$ level was used for making comparison among different treatments during storage.

\section{Results and Discussion}

\section{Sprout length}

Data regarding the sprout length of moth bean sprouts at room ant low temperature is presented in table 1. There was a progressive increase in the sprout length with increasing storage period both at room and low temperature. Sprout length under various treatments ranged from $1.53-2.33 \mathrm{~cm}$ and $1.56-2.11 \mathrm{~cm}$ during storage period of $48 \mathrm{~h}$ at room temperature and $120 \mathrm{~h}$ at low temperature, respectively. There was no significant difference in the sprout length under various treatments, except in ethanol treatment where reduced growth was observed during storage. Inhibition of sprout length was observed due to suppression of ethylene synthesis by ethanol vapour treatment. Results of present investigation were in accordance of Asoda et al., (2009). They studied that postharvest ethanol vapour treatment with ethanol pads inhibits ethylene production and prolongs the shelf-life of harvested broccoli.

\section{Sprout weight}

Data regarding the sprout weight of moth bean sprouts at room and low temperature is presented in table 2. There was a progressive increase in the sprout weight with increasing storage period both at room and low temperature. There was no considerable difference observed in the sprout weight under various treatments. Sprout weight under various treatments ranged from 0.55 to 0.78 $\mathrm{g} / 10$ sprouts and 0.53 to $0.83 \mathrm{~g} / 10$ sprouts during storage period of $48 \mathrm{~h}$ at room temperature and $120 \mathrm{~h}$ at low temperature, respectively.

\section{Total plate count (TPC)}

Data regarding the microbial content for each treatment at room and low temperature is presented in table 3. There was progressive increase in total plate count occurred with increasing storage period at both the temperatures. However, there was no considerable difference observed in total plate count under various treatments. Total plate count under various treatments ranged from 5.85 to $7.46 \log \mathrm{cfu} / \mathrm{ml}$ during storage period of $48 \mathrm{~h}$ at room temperature and from 5.85 to $6.89 \mathrm{log} \mathrm{cfu} / \mathrm{ml}$ during storage period of $120 \mathrm{~h}$ at low temperature. The results of present investigation was in with the findings of Goyal and Siddiqui (2014), where no significant effect of ethanol, hot water dip and UV-irradiation was observed on total plate count of mung bean sprouts during storage. However, several studies have been available on UV-C as a method to preserve the quality of different fruits and vegetables. Kulkarni and Karadbhajne (2015) studied the effect of UV radiation quality and shelf life of fresh cut fruits. They resulted that UV radiation treatment improved the quality and shelf life of fresh cut fruits and it is a highly efficient non thermal preservation technique for fresh cut fruits. Similarly Fernández-Suárez et al., 
(2013) studied the effect of UV-C on the bacterial diversity of Ataulfo mangoes and observed UV-C irradiation reduced the microbial load on the surface of mangoes immediately after treatment and the structure of bacterial communities was modified during storage.

\section{Sensory evaluation}

The Sensory score of appearance decreased significantly in all the treatment at room (up to $48 \mathrm{~h}$ ) and low temperature (up to $120 \mathrm{~h}$ ) storage condition (Table 5).

Table.1 Effect of different treatments on length $(\mathrm{cm})$ of moth bean sprouts during storage

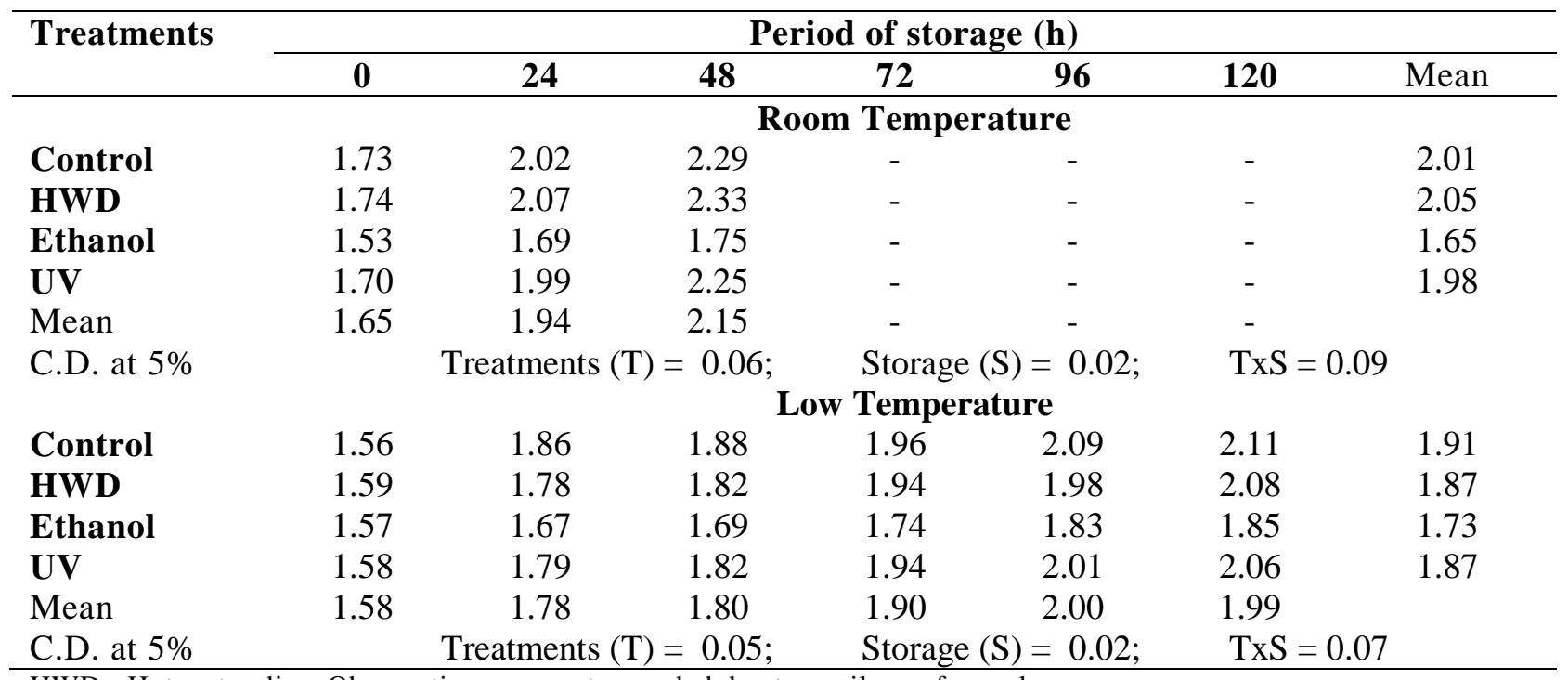

$\mathrm{HWD}=$ Hot water dip; -Observation were not recorded due to spoilage of samples

Table.2 Effect of different treatments on fresh weight (g/10 sprouts) of moth bean sprouts during storage

\begin{tabular}{|c|c|c|c|c|c|c|c|}
\hline \multirow[t]{2}{*}{ Treatments } & \multicolumn{7}{|c|}{ Period of storage (h) } \\
\hline & $\mathbf{0}$ & 24 & 48 & 72 & 96 & 120 & Mean \\
\hline & \multicolumn{7}{|c|}{ Room Temperature } \\
\hline Control & 0.55 & 0.61 & 0.74 & - & _ & - & 0.63 \\
\hline HWD & 0.61 & 0.72 & 0.78 & - & - & - & 0.70 \\
\hline Ethanol & 0.56 & 0.67 & 0.75 & - & - & - & 0.66 \\
\hline UV & 0.55 & 0.68 & 0.73 & - & - & - & 0.66 \\
\hline Mean & 0.57 & 0.67 & 0.75 & - & - & - & \\
\hline C.D. at $5 \%$ & \multicolumn{3}{|c|}{ Treatments $(\mathrm{T})=\mathrm{NS}$} & \multicolumn{2}{|c|}{$\begin{array}{l}\text { Storage }(S)=0.05 \\
\text { Temnerature }\end{array}$} & \multicolumn{2}{|c|}{$\mathrm{TxS}=\mathrm{NS}$} \\
\hline Control & 0.53 & 0.60 & 0.64 & 0.74 & 0.76 & 0.80 & 0.68 \\
\hline HWD & 0.62 & 0.68 & 0.70 & 0.76 & 0.79 & 0.83 & 0.73 \\
\hline Ethanol & 0.58 & 0.62 & 0.66 & 0.72 & 0.78 & 0.82 & 0.70 \\
\hline UV & 0.61 & 0.65 & 0.68 & 0.71 & 0.73 & 0.76 & 0.69 \\
\hline Mean & 0.59 & 0.64 & 0.67 & 0.73 & 0.77 & 0.80 & \\
\hline C.D. at $5 \%$ & \multicolumn{3}{|c|}{ Treatments $(T)=$ N.S; } & Storag & 0.01 & \multicolumn{2}{|c|}{$\mathrm{TxS}=\mathrm{N} \cdot \mathrm{S}$} \\
\hline
\end{tabular}

$\mathrm{HWD}=$ Hot water dip; Observations were not recorded due to spoilage of sample; NS: Non-significant 
Table.3 Effect of different treatments on total plate count $(\log \mathrm{cfu} / \mathrm{g})$ of moth bean sprouts during storage

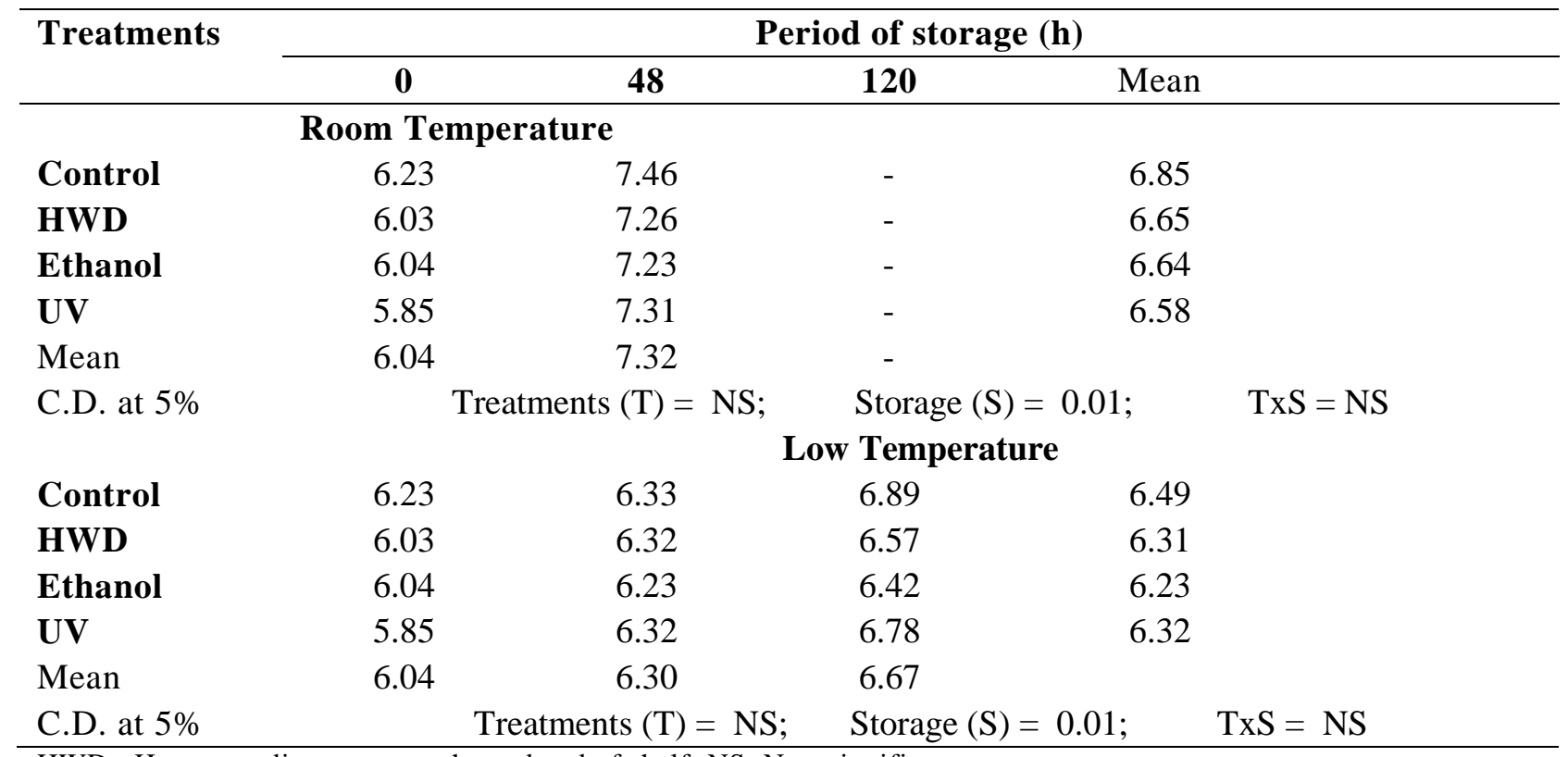

HWD= Hot water dip; - sprouts showed end of shelf; NS: Non-significant

Table.4 Effect of different treatments on organoleptic score (9 point hedonic) for appearance of moth bean sprouts during storage

\begin{tabular}{|c|c|c|c|c|c|c|c|}
\hline \multirow[t]{2}{*}{ Treatments } & \multicolumn{7}{|c|}{ Period of storage (h) } \\
\hline & $\mathbf{0}$ & 24 & 48 & 72 & 96 & 120 & Mean \\
\hline & \multicolumn{7}{|c|}{ Room Temperature } \\
\hline Control & 9.0 & 7.7 & 4.0 & - & - & - & 6.9 \\
\hline HWD & 9.0 & 8.3 & 5.4 & - & - & - & 7.6 \\
\hline Ethanol & 9.0 & 8.0 & 4.0 & - & - & - & 7.0 \\
\hline $\mathbf{U V}$ & 9.0 & 8.0 & 4.3 & - & - & - & 7.1 \\
\hline Mean & 9.0 & 8.0 & 4.4 & & & & \\
\hline C.D. at $5 \%$ & \multicolumn{3}{|c|}{ Treatments $(T)=0.33 ;$} & $\begin{array}{r}\text { St } \\
\mathbf{W} \text { Ter }\end{array}$ & $\begin{array}{l}S)= \\
\text { ture }\end{array}$ & \multicolumn{2}{|c|}{$\mathrm{TxS}=\mathrm{NS}$} \\
\hline Control & 9.0 & 8.7 & 8.0 & 7.7 & 6.3 & 4.3 & 7.3 \\
\hline HWD & 9.0 & 9.0 & 9.0 & 8.0 & 7.7 & 5.8 & 8.1 \\
\hline Ethanol & 9.0 & 8.8 & 8.4 & 7.3 & 7.0 & 4.1 & 7.4 \\
\hline $\mathbf{U V}$ & 9.0 & 8.7 & 8.0 & 7.7 & 7.0 & 4.3 & 7.5 \\
\hline Mean & 9.0 & 8.8 & 8.4 & 7.7 & 7.0 & 4.6 & \\
\hline C.D. at $5 \%$ & Treatm & tts $(\mathrm{T})=0.27$ & Sto & $(S)=$ & & NS & \\
\hline
\end{tabular}


Table.5 Effect of different treatments on organoleptic score (9 point hedonic) for taste of moth bean sprouts during storage

\begin{tabular}{|c|c|c|c|c|c|c|c|}
\hline \multirow[t]{2}{*}{ Treatments } & \multicolumn{7}{|c|}{ Period of storage (h) } \\
\hline & $\mathbf{0}$ & 24 & 48 & 72 & 96 & 120 & Mean \\
\hline & \multicolumn{7}{|c|}{ Room Temperature } \\
\hline Control & 9.0 & 6.3 & 4.0 & - & - & - & 6.4 \\
\hline HWD & 9.0 & 8.0 & 5.0 & - & - & - & 7.3 \\
\hline Ethanol & 9.0 & 7.0 & 4.0 & - & - & - & 6.7 \\
\hline $\mathbf{U V}$ & 9.0 & 7.0 & 4.0 & - & - & - & 6.7 \\
\hline Mean & 9.0 & 7.1 & 4.1 & - & - & - & \\
\hline C.D. at $5 \%$ & \multicolumn{2}{|c|}{ Treatments $(\mathrm{T})=0.43 ;$} & \multicolumn{3}{|c|}{$\begin{array}{l}\text { Storage }(S)=0.40 \\
\text { Low Temperature }\end{array}$} & $=0.80$ & \\
\hline Control & 9.0 & 8.0 & 8.0 & 7.3 & 6.3 & 4.0 & 7.1 \\
\hline HWD & 9.0 & 9.0 & 8.6 & 8.0 & 7.3 & 5.8 & 8.0 \\
\hline Ethanol & 9.0 & 8.0 & 7.7 & 7.3 & 6.3 & 4.0 & 7.1 \\
\hline UV & 9.0 & 8.7 & 8.0 & 7.0 & 7.0 & 4.0 & 7.3 \\
\hline Mean & 9.0 & 8.4 & 8.1 & 7.4 & 6.8 & 4.5 & \\
\hline C.D. at $5 \%$ & \multicolumn{2}{|c|}{ Treatments $(\mathrm{T})=0.41$} & \multicolumn{3}{|c|}{ Storage $(S)=0.39 ;$} & $=\mathrm{N}$. & \\
\hline
\end{tabular}

HWD= Hot water dip; - Observations were not recorded due to spoilage of samples NS: Non-significant

Table.6 Effect of different treatments on organoleptic score (9 point hedonic) for odour of moth bean sprouts during storage

\begin{tabular}{|c|c|c|c|c|c|c|c|}
\hline \multirow[t]{2}{*}{ Treatments } & \multicolumn{7}{|c|}{ Period of storage (h) } \\
\hline & $\mathbf{0}$ & 24 & 48 & 72 & 96 & 120 & Mean \\
\hline & \multicolumn{7}{|c|}{ Room Temperature } \\
\hline Control & 9.0 & 7.0 & 4.0 & - & - & - & 6.7 \\
\hline HWD & 9.0 & 7.9 & 4.6 & - & - & - & 7.2 \\
\hline Ethanol & 9.0 & 6.3 & 4.0 & - & - & - & 6.4 \\
\hline $\mathbf{U V}$ & 9.0 & 7.0 & 4.0 & - & - & - & 6.7 \\
\hline Mean & 9.0 & 7.1 & 4.2 & - & - & - & \\
\hline C.D. at $5 \%$ & \multicolumn{3}{|c|}{ Treatments $(\mathrm{T})=0.51 ;$} & $\begin{array}{r}\text { Sto } \\
\text { w Te }\end{array}$ & $\begin{array}{l}=0.48 \\
\text { ure }\end{array}$ & \multicolumn{2}{|c|}{$\mathrm{TxS}=0.99$} \\
\hline Control & 9.0 & 8.3 & 8.3 & 7.3 & 6.3 & 4.3 & 7.3 \\
\hline HWD & 9.0 & 8.3 & 8.3 & 8.0 & 7.7 & 5.0 & 7.8 \\
\hline Ethanol & 9.0 & 8.3 & 8.3 & 7.3 & 6.7 & 4.3 & 7.3 \\
\hline UV & 9.0 & 8.3 & 8.3 & 7.3 & 6.3 & 4.3 & 7.3 \\
\hline Mean & 9.0 & 8.3 & 8.3 & 7.5 & 6.8 & 4.5 & \\
\hline C.D. at $5 \%$ & Treatme & nts $(\mathrm{T})=0.41$ & Stor: & $(\mathrm{S})=$ & $\mathrm{TxS}$ & NS & \\
\hline
\end{tabular}


Table.7 Effect of different treatments on overall acceptability (9 point hedonic) of moth bean sprouts during storage

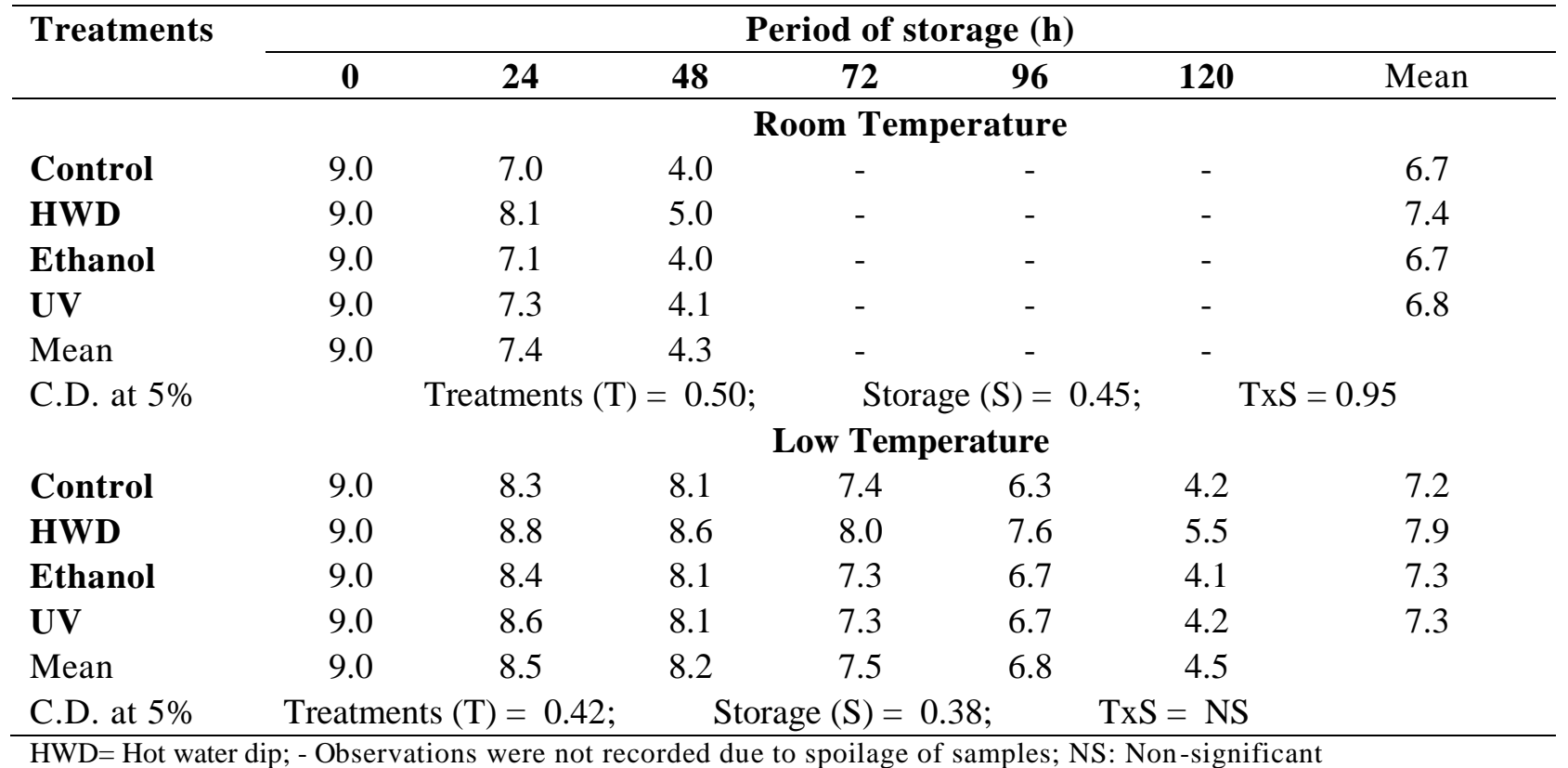

During storage, the organoleptic score (out of 9) for appearance was ranging from 9.0 (at initial period) to 4.0 (at the end of storage) amongst various treatments (Table 4). A significant change of taste was observed in all the treatment and control with advancement of storage condition (Table 6). The score for taste was ranges from 9.0 to 4.0 among the various treatments. Similar to appearance and taste, sensory score of odour was significantly decreased in all the treatments at both the storage temperature. The score for odour was 9.0 at starting day of storage and 4.0 at $48 \mathrm{~h}$ of storage at both the storage condition. There was no significant effect of various treatments on the odour score of sprouts throughout the storage period, except HWD treatment showing significant improvement in the organoleptic score over control. A significant decrease in scores for overall acceptability was observed in all the treatments with progress of storage period (Table 7). The sprout continued to show acceptable scores upto $24 \mathrm{~h}$ at room temperature and $96 \mathrm{~h}$ at low temperature storage conditions, except in hot water dip treatment, where the keeping quality of moth bean sprouts was maintained up to $48 \mathrm{~h}$ at room temperature and $120 \mathrm{~h}$ at low temperature. The decreased organoletic scores of sprouts during storage is the result of darkening of the root and cotyledons, development of dark streaks on the hypocotyl, and eventual development of sliminess, decay, and a musty odour (Lipton et al., 1981). In the present examination, amongst the various treatments, hot water dip treatment maintained higher sensory scores throughout the storage period. The result of present investigation was in accordance with Goyal and Siddiqui (2014). They also reported that mung bean sprouts remained acceptable upto $48 \mathrm{~h}$ and $120 \mathrm{~h}$ at room and low temperature conditions, respectively. The ethanol vapour and HWD treatments significantly enhanced the shelf life of mung bean sprouts, both at room as well as low temperature conditions of storage. The improvement in organoletic quality by HWD treatment was attributed to inhibition of enzymatic browning and due to leaching out 
of metabolites during dip treatment that were giving beany off flavour. Similarly, Bai et al., (2004) reported that the shelf life of ethanol and heat pretreated apple slices were 16 and 12 days, which was 7 and 3 to 4 days longer than that of non-pretreated controls (8 to 9 days), respectively. Thus, it can be concluded from the present study that keeping quality of moth bean sprouts can be maintained up to 48 $\mathrm{h}$ at room temperature and $120 \mathrm{~h}$ at low temperature, as against 24 and $96 \mathrm{~h}$, respectively under control conditions by subjecting the sprouts to hot water dip treatment of $50^{\circ} \mathrm{C}$ for $2 \mathrm{~min}$. This treatment could also represent a promising alternative to conventional methods for other cut-fruits \& vegetables also.

Based on these results, it can be concluded that different treatments resulted in improvement of quality of moth bean sprouts. Ethanol vapours and HWD treatment were more helpful in enhancing the shelf life of moth bean sprouts. Ethanol vapour treatment is effective in suppressing the sprout length. HWD treatment inhibits decay development on the surface without affecting color \& sensory quality during the storage. However, UV-irradiation treatments did not affect sprout length, sprout weight and sensory quality of bean sprouts significantly. In the light of the findings of this study, keeping quality of mothbean sprouts can be maintained well up to $48 \mathrm{~h}$ at room temperature and $120 \mathrm{~h}$ at low temperature as against 24 and $96 \mathrm{~h}$ under control conditions by subjecting the sprouts to hot water dip treatment of $50^{\circ} \mathrm{C}$ for $2 \mathrm{~min}$. This treatment could also represent a promising alternative to conventional methods for fruits and vegetables also.

\section{References}

Asoda, T., Terai, H., Kato, M. and Suzuki, Y. 2009. Effects of postharvest ethanol vapor treatment on ethylene responsiveness in broccoli. Postharvest Biol. Technol., 52: 216-220.

Bai, J., Baldwin, E.A., Fortuny, R.C.S., Mattheis, J.P., Stanley, R., Perera, C. and Brecth, J.K. 2004. Effect of pretreatment of intact 'Gala' apple with ethanol vapor, heat, or 1methylcyclopropene on quality and shelf life of fresh cut slices. J. American Society of Horticultural Sci., 129(4): 583-593.

Bhattacharya, S. 2010. Stress relaxation behavior of moth bean flour dough: product characteristic and solubility of model. J. Food Engi., 97: 539.

Day, B.P.F. 1990. Modified atmosphere packaging of selected prepared fruits and vegetables. In: Proc COST 91 Final Seminar Elsevier Science Publishers, Amsterdam, pp. 3230-3232

Fernandez-Suarez, R., Ramirez-Villatoro, G., Diaz-Ruiz, G., Eslava, C., Calderon, M., Navarro-Ocana, A., Trejo-Marquez, A. and Wacher, C. 2013. Effect of postharvest UV-C treatment on the bacterial diversity of Ataulfo mangoes by PCR-DGGE, survival of E. coli and antimicrobial activity. Front Microbial, 4: 134.

George, D.S., Razali, Z., Santhirasegaram, V. and Somasundram, C. 2015. Effect of postharvest ultraviolet-C treatment on the proteome changes in fresh cut mango (Mangifera indica L. cv. Chokanan). J. Sci. Food and Agri., 96: 2851-2860.

Ghavidel, R.A. and Prakash, J. 2007. The impact of germination and dehulling on nutrients, antinutrients, in vitro iron and digestibility of some legume seeds. Legume and Wheat Technol., 40: 12921299.

Goyal, A, Siddiqui S, Upadhyay N and Soni J. 2014. Effects of ultraviolet irradiation, pulsed electric field, hot water and ethanol vapours treatment on 
functional properties of mung bean sprouts. J. Food Sci. Technol., 51(4): 708-714.

Goyal, A. and Siddiqui, S. 2012. Effects of ultraviolet irradiation, pulsed electric field, hot water dip and ethanol vapours treatment on keeping and sensory quality of mung bean (Vigna radiata $\mathrm{L}$. Wilczek) sprouts. J. Food Sci. Technol., Online First ${ }^{\mathrm{TM}}$, 5th June 2012.

Goyal, A. and Siddiqui, S. 2014. Effects of ultraviolet irradiation, pulsed electric field, hot water dip and ethanol vapours treatment on keeping and sensory quality of mung bean (Vigna radiata $\mathrm{L}$. Wilczek.) sprouts. J. Food Sci. Technol., 51(10): 2664-2670.

Khattak, A.B., Zeb, A., Bibi, N. and Khattak, M.S. 2008. Effect of germination time and type of illumination on proximate composition of chickpea seed (Cicer arietinum L.). American J. Food Technol., 3(1): 24-32.

Kulkarni, S. and Karadbhajne, S. 2015. Influence of UV light exposure on shelf life extension of freshcut fruits. Int. J. Adv. Res., 3(5): 1296-1306.

Lipton, W.J., Asai, W.K. and Fouse, D.C. 1981. Deterioration and $\mathrm{CO}_{2}$ and ethylene production of stored mung bean sprouts. J. American Society for Horticultural Sci., 106(6): 817-820.

Salve, R.V. and Mehrajfatema, Z.M. 2011. Effect of Different Pretreatment on Trypsin Inhibitor Activity and Nutritional Composition of Moth Bean and its Utilization in Fortified Cake. World J. Dairy \& Food Sci., 6(2): 212218.

\section{How to cite this article:}

Simran Arora, Saleem Siddiqui and Rakesh Gehlot. 2017. Effects of Ultraviolet Irradiation, Hot Water Dip and Ethanol Vapours Treatment on Keeping Quality of Moth Bean (Phaseolus aconitifolius Jacq.) Sprouts. Int.J.Curr.Microbiol.App.Sci. 6(8): 2143-2151. doi: https://doi.org/10.20546/ijcmas.2017.608.254 